\title{
Taxonomic revision of the subterranean genus Virpazaria Gittenberger, 1969 (Gastropoda, Spelaeodiscidae)
}

\author{
Zoltán FEHÉR $^{1, *}$, Tamás DELI ${ }^{2}$, Zoltán P. ERÖSS ${ }^{3} \&$ Romilda LIKA ${ }^{4}$ \\ ${ }^{1}$ Department of Zoology, Hungarian Natural History Museum, \\ Baross u. 13, Budapest, H-1088, Hungary. \\ ${ }^{2}$ Móricz Zsigmond u. 2, Gyomaendrőd, H-5500, Hungary. \\ ${ }^{3}$ Bem u. 36., Budapest, H-1151, Hungary. \\ ${ }^{4}$ Departament of Biology, Faculty of Natural Sciences, Tirana University, \\ Bulevardi Zogu i Parë, Tiranë, AL-1001, Albania. \\ *Corresponding author: feher.zoltan@nhmus.hu \\ ${ }^{2}$ Email: virpazaria@gmail.com \\ ${ }^{3}$ Email: erosspeter@hotmail.com \\ ${ }^{4}$ Email: romildalika@gmail.com \\ ${ }^{1}$ urn:1sid:zoobank.org:author:E801EC76-8B1E-450B-993E-BBBE57C00EA9
${ }^{2}$ urn:lsid:zoobank.org:author:A33DCDF3-6293-4B34-B1DD-330211905D74
${ }^{3}$ urn:1sid:zoobank.org:author:0B2C74A7-0001-4E25-984C-88CB0C705313
${ }^{4}$ urn:1sid:zoobank.org:author:9662552B-B203-43FF-B427-4330080E1CBA
}

\begin{abstract}
Virpazaria Gittenberger, 1969 is distributed in the Balkan Peninsula (Albania, Montenegro and Croatia) and inhabits the shallow subterranean habitat (MSS) on limestone base rock. Reviewing historical and recently collected material, two species, Virpazaria (Virpazaria) gittenbergeri Fehér \& Eröss sp. nov. and Virpazaria (Virpazaria) pesici Fehér \& Deli sp. nov., are introduced as new to science. The conservation status of the new species are assessed using IUCN criteria. Two taxa, Virpazaria (Virpazaria) pageti alexanderi Reischütz \& Subai, 2012 and Virpazaria (Aemiliella) ripkeni pastorpueri Reischütz et al., 2011, are synonymized with their nominate subspecies. Some new distribution records, as well as geological and geomorphological data about the known locations for Virpazaria, are presented.
\end{abstract}

Keywords. Balkan, shallow subterranean habitat (MSS), new taxa, microendemic species, limestone habitat.

Fehér Z., Deli T., Erőss Z.P. \& Lika R. 2019. Taxonomic revision of the subterranean genus Virpazaria Gittenberger, 1969 (Gastropoda, Spelaeodiscidae). European Journal of Taxonomy 558: 1-25.

https://doi.org/10.5852/ejt.2019.558

\section{Introduction}

Virpazaria Gittenberger, 1969 is a subterranean land snail genus occurring around the transboundary Lake Skadar (in Albania and Montenegro) as well as in the northern part of Kotor Bay (in Montenegro 
and Croatia). Previously, Virpazaria was believed to be an obligate troglobiont, but later findings have demonstrated that - similarly to many other land snail genera in the Balkans such as Agardhiella Hesse, 1923, Balcanodiscus Riedel \& Urbański, 1964, Gyralina Andreae, 1902, Klemmia Gittenberger, 1969, Pholeoteras Sturany, 1904, Sciocochlea C.R. Boettger, 1935, Spelaeodiscus Brusina, 1886, Troglovitrea Negrea \& Riedel, 1968, Tsoukatosia Gittenberger, 2000 and many species in Platyla Moquin-Tandon, 1856 or Vitrea Fitzinger, 1833 - it rather prefers superficial underground compartments (also known as the 'Mesovoid Shallow Substratum' or 'Milieu Souterrain Superficiel', widely abbreviated as MSS; see, e.g., Juberthie et al. 1980, 1981; Camacho 1992; Culver \& Pipan 2014; Mammola et al. 2016). It is still disputed whether such a bedrock MSS habitat is characteristically different from caves or it can be considered as just the extension of the cave system, and therefore whether its fauna is composed of troglobionts of wider ecological tolerance or there are certain specialized elements exclusive of MSS (see Mammola et al. 2016 for a review). Either way, caves are interconnected with the bedrock's crevice network, giving a reasonable explanation for occasional cave records of this genus.

Extensive field surveys applying the 'scratch \& flotate' sampling method (Páll-Gergely et al. 2018) significantly increased the number of known populations and the amount of available material of subterranean gastropods in the past decade. In this paper we revise the genus Virpazaria, describe new taxa, present new distribution records and try to draw taxonomy-related conclusions. As little is known about the ecology of MSS-dwelling gastropods (Arndt \& Subai 2013; Rendoš et al. 2014) and practically nothing about their habitat preferences in terms of the type, age and morphology of bedrock, we present data about the geology and geomorphology of the sampled habitats.

\section{Material and methods}

The new samples were collected between 2015 and 2018. Sampling was done using the 'scratch \& flotate' approach. First, we looked for superficial fissures, cracks and holes in limestone cliffs from where it was possible to scratch out fine granulate material by applying long and narrow handrakes. Shells were then separated by flotation in water.

For non-type material listed in the 'Material examined' sections, the number of specimens in each lot is not generally specified, as there is often uncertainty regarding how the specimens from a collecting event have been distributed between official institutions and the private collections of the collectors.

Albanian and former Yugoslavian geological maps (MMKS 1983; Mikinčić 1953) were used to identify the types and ages of the bedrock at the georeferenced sites.

Digital pictures were made using a Nikon DS-Ri2 camera attached to a Nikon SMZ25 stereo microscope and then combined into focus stack images with Nikon's NIS software. ImageJ 1.49 scientific image analyzing software (Schneider et al. 2012) was used for measurements. We measured shell height, shell width, aperture height and aperture width (see Páll-Gergely et al. 2018: fig. 1), and counted the number of ribs on the last whorl, as well as the number of whorls $( \pm 0.25)$ according to Kerney \& Cameron (1979: 13).

\section{Abbreviations used:}

$\begin{array}{ll}\text { CNHM } & =\text { Croatian Natural History Museum, Zagreb, Croatia } \\ \text { DT } & =\text { Collection Tamás Deli, Gyomaendrőd, Hungary } \\ \text { ER } & =\text { Collection Zoltán Péter Eröss, Budapest, Hungary } \\ \text { HNHM } & =\text { Hungarian Natural History Museum, Budapest, Hungary } \\ \text { NHMW } & =\text { Naturhistorisches Museum Wien, Vienna, Austria } \\ \text { NHMW-E } & =\text { Edlauer Collection in NHMW }\end{array}$




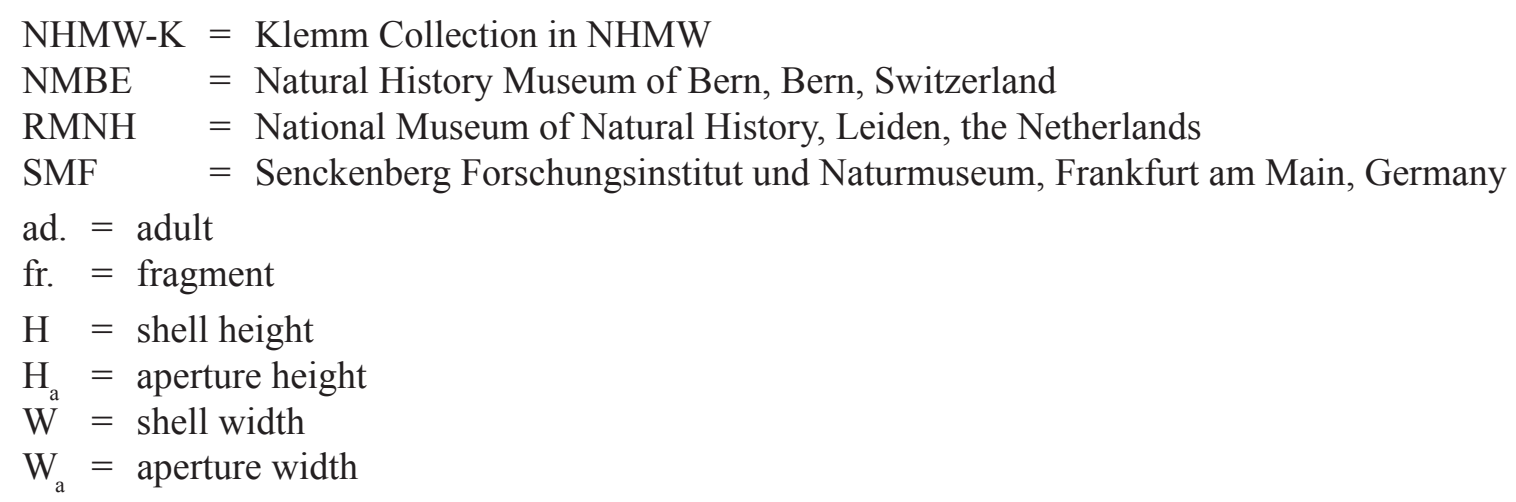

\section{Results}

Class Gastropoda Cuvier, 1795

Subclass Heterobranchia Burmeister, 1837

Order Stylommatophora A. Schmidt, 1855

Superfamily Pupilloidea W. Turton, 1831

Family Spelaeodiscidae Steenberg, 1925

Genus Virpazaria Gittenberger, 1969

\section{Type species}

Virpazaria adrianae Gittenberger, 1969, by original designation.

\section{Diagnosis}

Shell discoid, dextral, ribbed, colourless (weathered specimens are opaque white), peristome attached, thickened, usually with knob- or tooth-like prominences on palatal and/or basal sides. Peristome insertions are connected; this parietal connection varies from a swollen bulge to a lamelliform flap; in some species this flap might cover a significant part of the aperture in frontal view. Aperture somewhat narrow and moon-shaped.

\section{Remarks}

According to Gittenberger (1969, 1975) as well as Reischütz \& Reischütz (2009), Virpazaria is distinguished from the conchologically similar genus Spelaeodiscus by the continuous peristome, i.e., the presence of a parietal bulge or flap that connects the peristome insertions. Spelaeodiscus virpazarioides Páll-Gergely \& Fehér, 2018 also possesses a callous parietal structure, but it is much smaller in proportion to the size of the whole aperture. Also, the narrower, crescent-shaped aperture is a good feature to tell Virpazaria apart from related genera.

Due to their hidden life, in most of the cases only empty shells are found. So far, there is one reported case when Virpazaria, more specifically two individuals of $V$. deelemanorum, were found alive (Gittenberger 1975). Having no pigmented eyes, they are presumably blind, as is usual for subterranean animals. Comparing their genitals to those of Spelaeodiscus, Klemmia and Aspasita Westerlund, 1889 (Bole 1965; Hudec 1965; Gittenberger 1975; Subai \& Dedov 2008), one might discover differences in terms of proportional lengths of certain reproductive organs, and there are certain structures that are called differently by different authors (e.g., the same short protrusion at the border of penis and epiphallus is referred to as flagellum by Gittenberger (1975) and penial caecum by Schileyko (1998)). However, the overall arrangement of the genitalia is similar in these four genera, and no genus-specific differences could be found on the basis of the available literature. 


\section{A key to species of Virpazaria}

1. Two lamellae, one palatal and one basal, reach deeply (more than $1 / 10$ of whorl) into the aperture ... V. (Aemiliella) ripkeni Gittenberger, 1969

- No deeply reaching lamellae in the aperture, just knob(s) or on elongated thickening parallel with

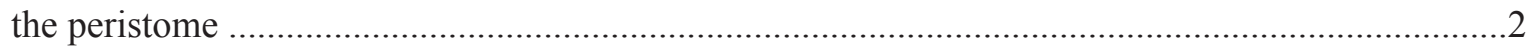

2. In frontal view, the crescent-shaped hole of the aperture is well visible .........................................

- In frontal view, the hole of the aperture is almost or entirely covered ...........................................5

3. One knob and a basal thickening on the peristome .............$\left(V_{0}\right)$ gittenbergeri Fehér \& Eröss sp. nov.

- Two knobs on the peristome ..... .4

4. Shell width greater than $5 \mathrm{~mm}$ V. (V.) pesici Fehér \& Deli sp. nov.

- Shell width less than $5 \mathrm{~mm}$ V. (V.) deelemanorum Gittenberger, 1969

5. Upper side of the shell is entirely flat in frontal view V. (V.) stojaspali Reischütz et al., 2009

- Shell is conical in frontal view

6. No knobs on the peristome .7

- At least one knob on the peristome 8

7. Very narrow umbilicus .....V. (V.) aspectulabeatidis Reischütz et al. in Reischütz \& Reischütz, 2009

- Wide, perspectivical umbilicus .. (V.) pageti Gittenberger, 1969

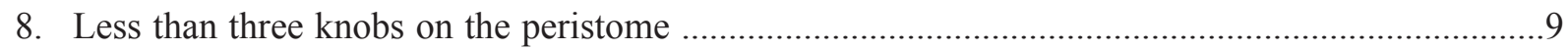

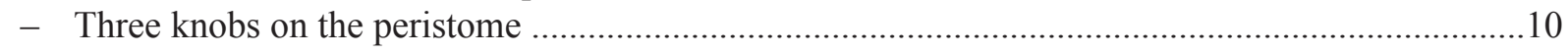

9. An elongated basal thickening and a detached palatal knob on the peristome

- Palatal knob is fused to the basal thickening of the peristome

V. (V.) backhuysi Gittenberger, 1969 V. (V.) gittenbergeri Fehér \& Eröss sp. nov.

10. In bottom-view the umbilicus seems wider than $1 / 4$ of the shell width, in frontal view the shell is flat conical $(\mathrm{H}: \mathrm{W}<2: 3)$

V. (V.) adrianae Gittenberger, 1969

- In bottom-view the umbilicus seems narrower than $1 / 4$ of the shell width, in frontal view the shell is conical $(\mathrm{H}: \mathrm{W} \approx 2: 3)$

.V. (V.) nicoleae Reischütz \& Reischütz, 2012

Virpazaria (Virpazaria) adrianae Gittenberger, 1969

Fig. 1A-F

Virpazaria (Virpazaria) adrianae Gittenberger, 1969: 298-299, fig. 4.

Virpazaria (Virpazaria) adrianae - Gittenberger 1975: 268. — Welter-Schultes 2012: 211, unnumbered fig.

\section{Diagnosis}

Discoid, shouldered shell, barely raised spire, wide umbilicus. Aperture crescent-shaped, most of it but the sinus region covered by a parietal flap in frontal view. Three wide knobs at basal-palatal peristome.

\section{Material examined}

\section{Holotype}

MONTENEGRO • W of Virpazar, Velika Jama, at Mt. Soko near Dupilo; Dabović leg.; "Trissexodon kuščeri" [original label]; NHMW-E 57441. 
FEHÉR Z. et al., Taxonomic revision of Virpazaria (Gastropoda, Spelaeodiscidae)

Paratypes

MONTENEGRO • > 30 spec.; same collection data as for holotype; NHMW-E 57441a $\bullet 1$ spec.; same collection data as for holotype; SMF123347 • 2 spec.; same collection data as for holotype; RMNH $53303 \cdot 1$ spec.; same collection data as for holotype; NHMW-K $29619 \cdot 2$ spec.; same locality as holotype; Kuščer leg.; Apr.1936; SMF 53886.

\section{Other material}

MONTENEGRO • 6 spec.; "Grotte Grbočica” [Pećina Grbočica]; 10 Jul. 1936; Dabović leg.; [on label indicated as paratype]; NHMW-E 48634 - 3 spec.; "Grotte Grbočica" [Pećina Grbočica]; 10 Jul. 1936; Dabović leg.; [on label indicated as paratype]; NHMW-E $48092 \cdot 1$ spec.; Vrelo kod Jabukovog dola; Dabović leg.; [on label indicated as paratype]; NHMW-E $48486 \cdot 3$ spec.; [without locality]; "Trissexodon montenegrina n. sp. Smmlg. Kuščer, Smmlg. Edlauer"; ex. Kǔšcr; NHMW $79007 \cdot$ many spec.; Sokopećina; ex. Edlauer; NHMW 79008 - 7 spec.; Pećina na ostrvu Vranjini [cave on Vranjina Island]; Kuščer leg.; NHMW 78990 • Pećina na ostrvu Vranjini [cave on Vranjina Island]; Kuščer leg.; NHMW-K $64035 \cdot 3.5 \mathrm{~km}$ N of Virpazar, on road to Rijeka Crnojevića, Vidikovac Observation Point; $42.2547^{\circ} \mathrm{N}, 19.0896^{\circ} \mathrm{E} ; 150 \mathrm{~m}$ alt.; 25 May 2015; T. Deli, Z. Erőss and Z. Fehér leg.; HNHM 103419 • W of Virpazar, $1.2 \mathrm{~km}$ from Dupilo, S side of Mt Tor; $42.2527^{\circ} \mathrm{N}, 19.0662^{\circ} \mathrm{E} ; 85 \mathrm{~m}$ alt.; 20 Oct. 2017; T. Deli, Z. Erőss, A. Hunyadi and B. Páll-Gergely leg.; DT $\bullet$ W of Virpazar, $1.2 \mathrm{~km}$ from Dupilo, S side of Mt Tor; $42.2527^{\circ} \mathrm{N}, 19.0662^{\circ}$ E; 85 m alt.; 20 Oct. 2017; T. Deli, Z. Erőss, A. Hunyadi and B. PállGergely leg.; ER - NNW of Virpazar, 0.4 km W of Poseljani, on road to Rijeka Crnojevića; $42.3060^{\circ} \mathrm{N}$, $19.0483^{\circ}$ E; 130 m alt.; 20 Oct. 2017; T. Deli, Z. Eröss, A. Hunyadi and B. Páll-Gergely leg.; DT • NNW of Virpazar, $0.4 \mathrm{~km}$ W of Poseljani, on road to Rijeka Crnojevića; $42.3060^{\circ} \mathrm{N}, 19.0483^{\circ} \mathrm{E} ; 130 \mathrm{~m}$ alt.; 20 Oct. 2017; T. Deli, Z. Erőss, A. Hunyadi and B. Páll-Gergely leg.; ER • Začir, Pečina u Pečkom Brdu, above village; 20 Jul. 1972; L. Pintér, P. Subai and A. Szigethy leg.; HNHM $72071 \bullet$ Komarno, Jabukov Do Cave; 3 Jun. 1978; W.J.M. Maassen leg.; NMBE 539837.

\section{Dimensions}

H 1.6-1.9 mm; W 3.0-3.5 mm.

\section{Distribution}

This is the most frequent species of the genus. Its range is northwest of Lake Skadar in Montenegro. The following locations are mentioned in the literature: Velika Jama near Dupilo, Pečina Grbočica near Trnovo, Pečina u Pečkom Brdu near Začir, Pečina Ostrin Vranjini northeast of Virpazar, Babotuša Spilja near Trnovo and Jabukov do Pečina near Komarno (Gittenberger 1969, 1975). Recently discovered new sites fall within the boundaries of the previously known range. All georeferenced records (and probably the non-georeferenced ones too) came from Lower Triassic limestone (Fig. 2).

Virpazaria (Virpazaria) aspectulabeatidis Reischütz et al. in Reischütz \& Reischütz, 2009

Virpazaria aspectulabeatidis A. Reischütz, P.L. Reischütz \& Subai in A. Reischütz \& P.L. Reischütz, 2009: 56, figs 4-5.

Virpazaria aspectulabeatidis - Subai 2009: 109, fig. 9. - Welter-Schultes 2012: 211.

\section{Diagnosis}

Discoid, shouldered shell, low but visibly raised spire. 60-65 ribs on body whorl. Aperture very narrow, crescent-shaped, entirely covered by a parietal flap in frontal view. In bottom view, very narrow umbilicus, parietal flap and palatal peristome form like two straight parallel lines. 


\section{Material examined}

Holotype

MONTENEGRO • Rumija Mts, rocks above Bes; Jul. 2008; A. Reischütz, N. Reischütz and P.L. Reischütz leg.; NHMW 106689.

\section{Paratypes}

MONTENEGRO • 1 spec.; Mt Kroništar, S slope, approx. $10 \mathrm{~km}$ E of Đuravci (in direction to Ostros, S of Lake Skadar); 350 m alt.; 16 Sep. 2006; P. Subai leg.; SMF 333501 • 1 spec.; Mt Kroništar, S slope,

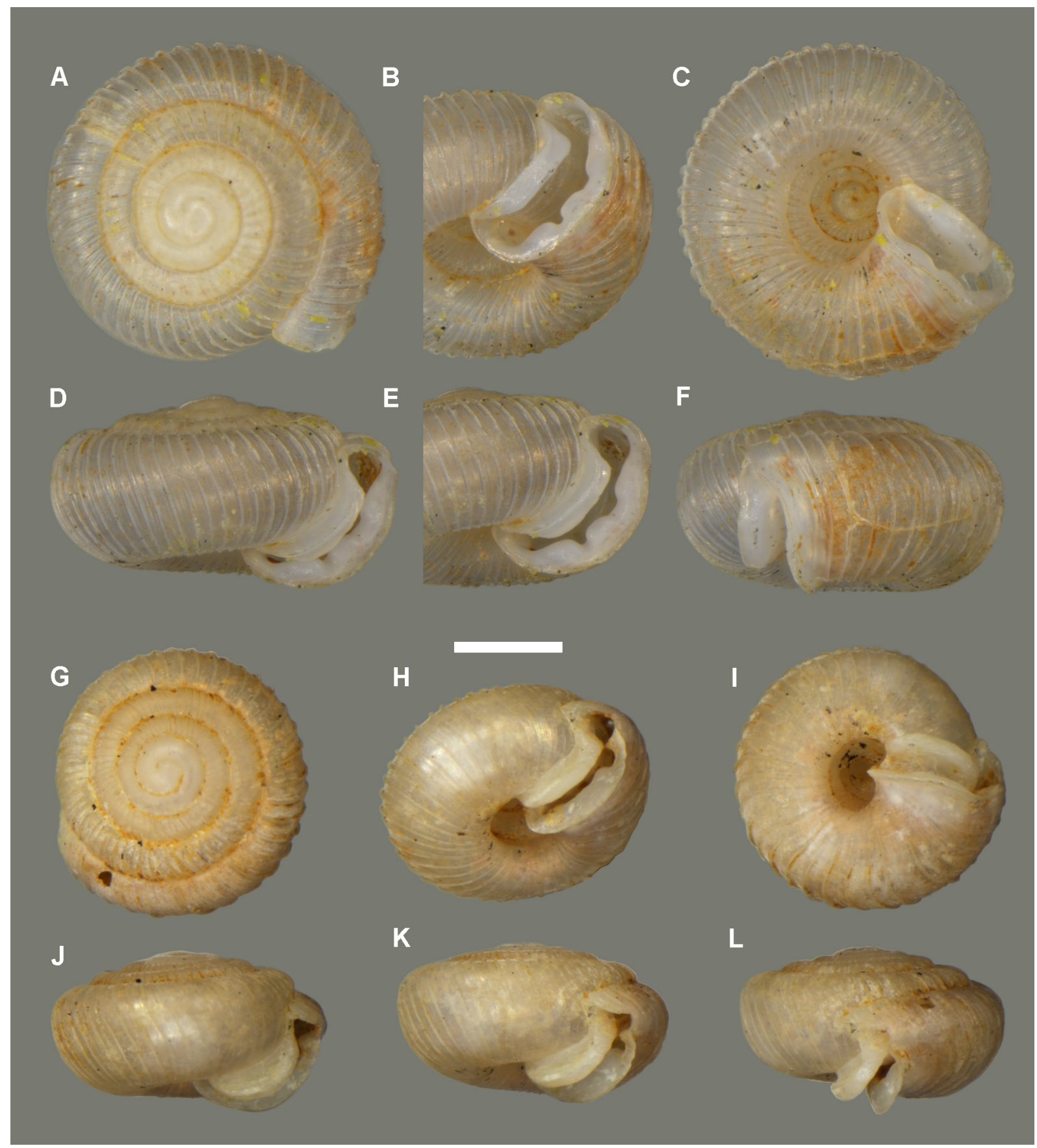

Fig. 1. Shells of species of Virpazaria Gittenberger, 1969. A-F. Virpazaria (Virpazaria) adrianae Gittenberger, 1969, holotype (NHMW-E 57441). G-L. Virpazaria (Virpazaria) backhuysi Gittenberger, 1969, holotype (NHMW-E 48856). Scale bar $=1 \mathrm{~mm}$. 
FEHÉR Z. et al., Taxonomic revision of Virpazaria (Gastropoda, Spelaeodiscidae)

approx. $10 \mathrm{~km}$ E of Đuravci (in direction to Ostros, S of Lake Skadar); 350 m alt.; 16 Sep. 2006; P. Subai leg.; NMBE 539842.

Other material

MONTENEGRO - Rumija Mts, Besa, Krone i Besit, $2 \mathrm{~km} \mathrm{~S}$ of Donji Murići junction on VirpazarOstros road; 320 m alt.; 42.1424 N, $19.2197^{\circ}$ E; 19 Oct. 2017; T. Deli, Z. Erőss, A. Hunyadi and B. Páll-Gergely leg.; DT.

\section{Dimensions}

H 2.1-2.3 mm; W 3-3.5 mm.

\section{Distribution}

This species has a very restricted range west of Lake Shkodër at the foot of the Rumija Mountains in Montenegro (Reischütz \& Reischütz 2009; Subai 2009). Apart from the type locality there is another literature record, namely "Đuravci, $10 \mathrm{~km}$ to Ostros" (Subai 2009). None of the published distribution records were georeferenced; thus, it is difficult to say how far these locations are from one another. The site where we found this species is likely identical to, or very close to, the type locality and its bedrock type is Upper-Middle Jurassic limestone. At all three sites, this species was reported to co-occur with V. stojaspali (Fig. 2).

Virpazaria (Virpazaria) backhuysi Gittenberger, 1969

Fig. 1G-L

Virpazaria (Virpazaria) backhuysi Gittenberger, 1969: 299-301, fig. 5.

Virpazaria (Virpazaria) backhuysi - Welter-Schultes 2012: 212.

\section{Diagnosis}

Small, discoid and shouldered shell, low but raised spire, wide umbilicus. Callous thickening along entire basal peristome, a smaller knob on palatal peristome. High and thick parietal flap reaching almost up to angular junction. Aperture crescent-shaped, all of it but the sinus region covered by a parietal flap in frontal view.

\section{Material examined}

Holotype

MONTENEGRO・Virpazar, “Cp.360”; Dabović leg.; NHMW-E 48856.

\section{Dimensions}

H $1.5 \mathrm{~mm}$; W $2.5 \mathrm{~mm}$ (holotype).

\section{Distribution}

Only the holotype specimen is known, which came from the Edlauer Collection and was probably collected in the 1930s. On the label only "Virpazar Cp.360" is stated. Virpazar is a small historical town with a fortress. In past decades, various malacologists have sampled in and around Virpazar, including E. Gittenberger, H. Nordsieck, A. and P.L. Reischütz, P. Subai and the authors of the present paper, but no one has been able to refind this enigmatic species. This either means that $V$. backhuysi has a very narrow range and/or is a locally very rare species, or that we searched in all the wrong places. In case of old museum material, the possibility of a past mix-up can never be excluded (see also the doubt regarding the real origin of the type series of $V$. ripkeni), but it is also feasible that the label information refers to 
the area around Virpazar in a broader sense. Due to this uncertainty we cannot conclude anything about its preferred bedrock type.

Virpazaria (Virpazaria) deelemanorum deelemanorum Gittenberger, 1975

Virpazaria (Virpazaria) deelemanorum Gittenberger, 1975: 268-269, figs 3 (shell), 4-5 (genitals), table I.1.

Virpazaria (Virpazaria) deelemanorum - Welter-Schultes 2012: 212 (in part).

\section{Diagnosis}

Discoid shell, hardly emerging spire, body whorl silhouette symmetrically rounded. Wide umbilicus. Aperture crescent-shaped, mostly visible in frontal view. Two - more or less equal-sized - knobs on palatal peristome. Callous thickening on peristome between its columellar junction and upper palatal knob.

\section{Material examined}

\section{Holotype}

MONTENEGRO • E of Podgorica, Mt. Fundina, Čafa Pješatica Cave; A.P.B. Deeleman leg.; RMNH 55031.

\section{Paratypes}

MONTENEGRO - 1 spec.; same collection data as for holotype; includes genital preparation RMNH 806a,b; RMNH 55032 • 1 spec.; same locality as for holotype; E. Gittenberger leg.; RMNH $55033 \bullet 1$ spec.; Pećina od Zavora near Peuta, ENE of Podgorica; Deeleman-Reinhold leg.; RMNH 55034 [not seen].

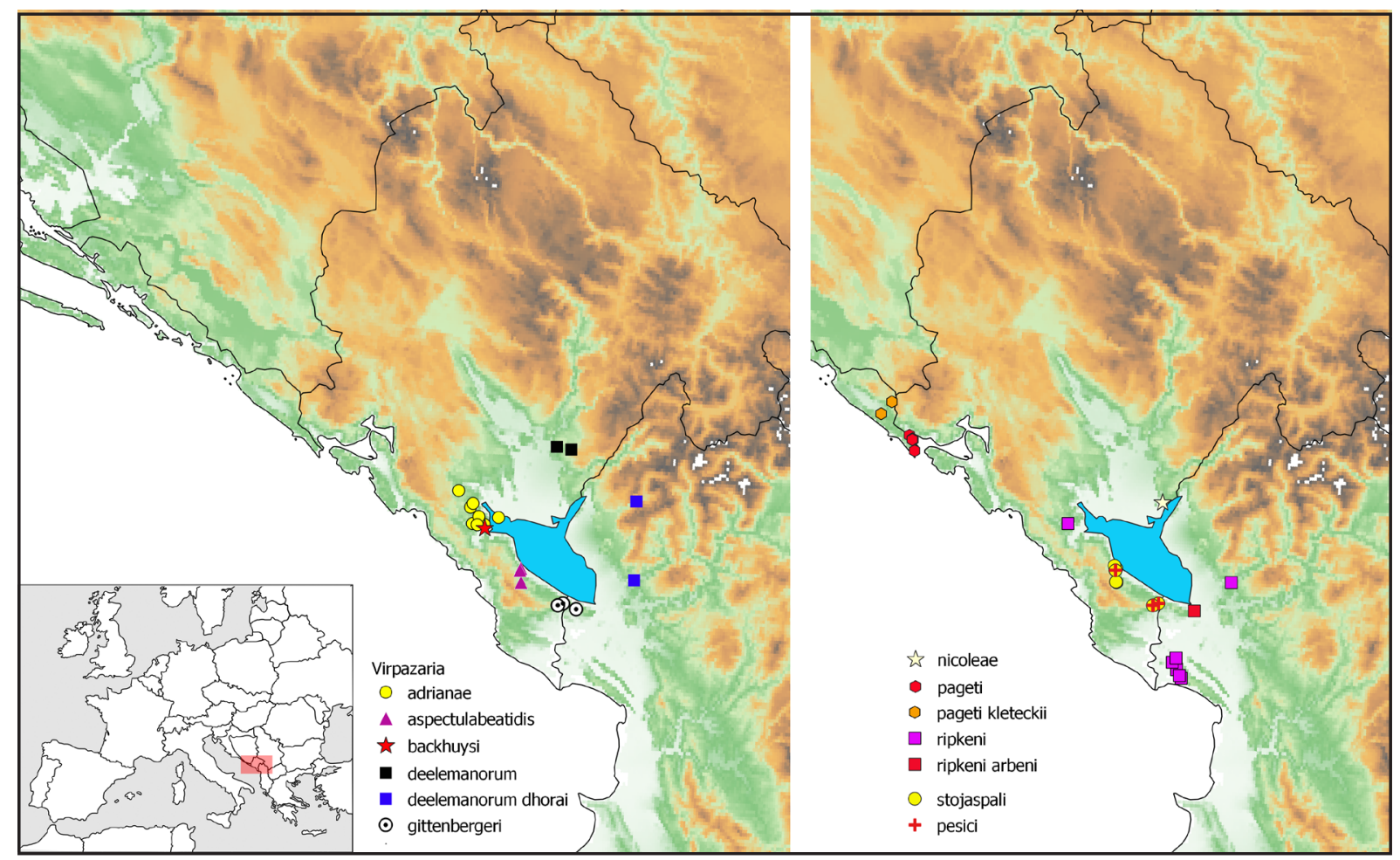

Fig. 2. Distribution of species of Virpazaria Gittenberger, 1969 in the western part of the Balkan Peninsula. 
FEHÉR Z. et al., Taxonomic revision of Virpazaria (Gastropoda, Spelaeodiscidae)

\section{Dimensions}

H 2.1-2.3 mm; W 3.7-4.2 mm.

Virpazaria (Virpazaria) deelemanorum dhorai Reischütz et al., 2010

Fig. 3A-E

Virpazaria dhorai A. Reischütz, N. Reischütz \& P. L. Reischütz, 2010: 29, figs 1-2.

Virpazaria deelemanorum - Welter-Schultes 2012: 212 (in part).

Virpazaria (Virpazaria) deelemanorum dhorai - Gittenberger 2015: 27, figs 9-10.

\section{Diagnosis}

Compared to nominate subspecies, shell somewhat smaller and lower palatal knob palpably larger.

\section{Material examined}

Holotype

ALBANIA • rocks between Xhajë and Makaj, along Koplik-Bogë road; Jul. 2009; A. Reischütz, N. Reischütz and P.L. Reischütz leg.; NHMW 107224.

\section{Other material}

ALBANIA - Shkodër district, Drisht, right bank of Kiri River opposite fortress hill; $42.1304^{\circ} \mathrm{N}$, $19.609^{\circ}$ E; 90 m alt.; 28 Jun. 2016; Erőss, Fehér, Szekeres and Grego leg.; HNHM 103421 • Shkodër District, Drisht, right bank of Kiri River opposite fortress hill; $42.1304^{\circ} \mathrm{N}, 19.609^{\circ} \mathrm{E} ; 90 \mathrm{~m}$ alt.; $28 \mathrm{Jun}$. 2016; Erőss, Fehér, Szekeres and Grego leg.; NHMW 110430/MN/0987 • Malësia district, 0.5 km NE of Xhajë; $42.3306^{\circ} \mathrm{N}, 19.6057^{\circ} \mathrm{E} ; 650 \mathrm{~m}$ alt.; 4 Jul. 2015; Erőss, Fehér and Grego leg.; HNHM 103423 - Malësia district, $0.5 \mathrm{~km} \mathrm{NE}$ of Xhajë; $42.3306^{\circ} \mathrm{N}, 19.6057^{\circ} \mathrm{E} ; 650 \mathrm{~m}$ alt.; 4 Jul. 2015; Eröss, Fehér and Grego leg.; NHMW 110430/MN/0988.

\section{Dimensions}

H 1.8-2.25 mm; W 3.4-4.2 mm.

\section{Remarks}

Gittenberger (2015) mentioned that the protoconch of $V$. $d$. dhorai is coarsely granular and that the teleoconch has some irregular radial lines and a very fine microsculpture of incised spiral lines. This, however, is discernible on fresh specimens. Only a few specimens of the nominate form (the types) are known and all are too weathered to observe anything about their shell microsculpture; it is also difficult to conclude whether it is a consistent feature that the palatal knobs are equal-sized in the nominate form. Gittenberger (2015) was somewhat uncertain about the systematic position of the two taxa, but due to the limited amount of material of $V . d$. deelemanorum, he kept them as subspecies.

\section{Distribution}

The range of this species can be found east-northeast of the Shkodër Basin (Albania and Montenegro) (Gittenberger 1975). The nominate subspecies is known from two locations at Mt Fundina (northeast of Podgorica in Montenegro), ca 5-6 km from each other, namely Pecina Cafa Pesatica and Pecina od Zavora near Peuta. The subspecies dhorai was found east of the Shkodër Basin, in Bogë Valley near Xhajë and in the Kiri River Valley near Drisht. The newly discovered latter site extends the known range of this species southwards and indicates that further research in this area might reveal additional locations and a larger range. 


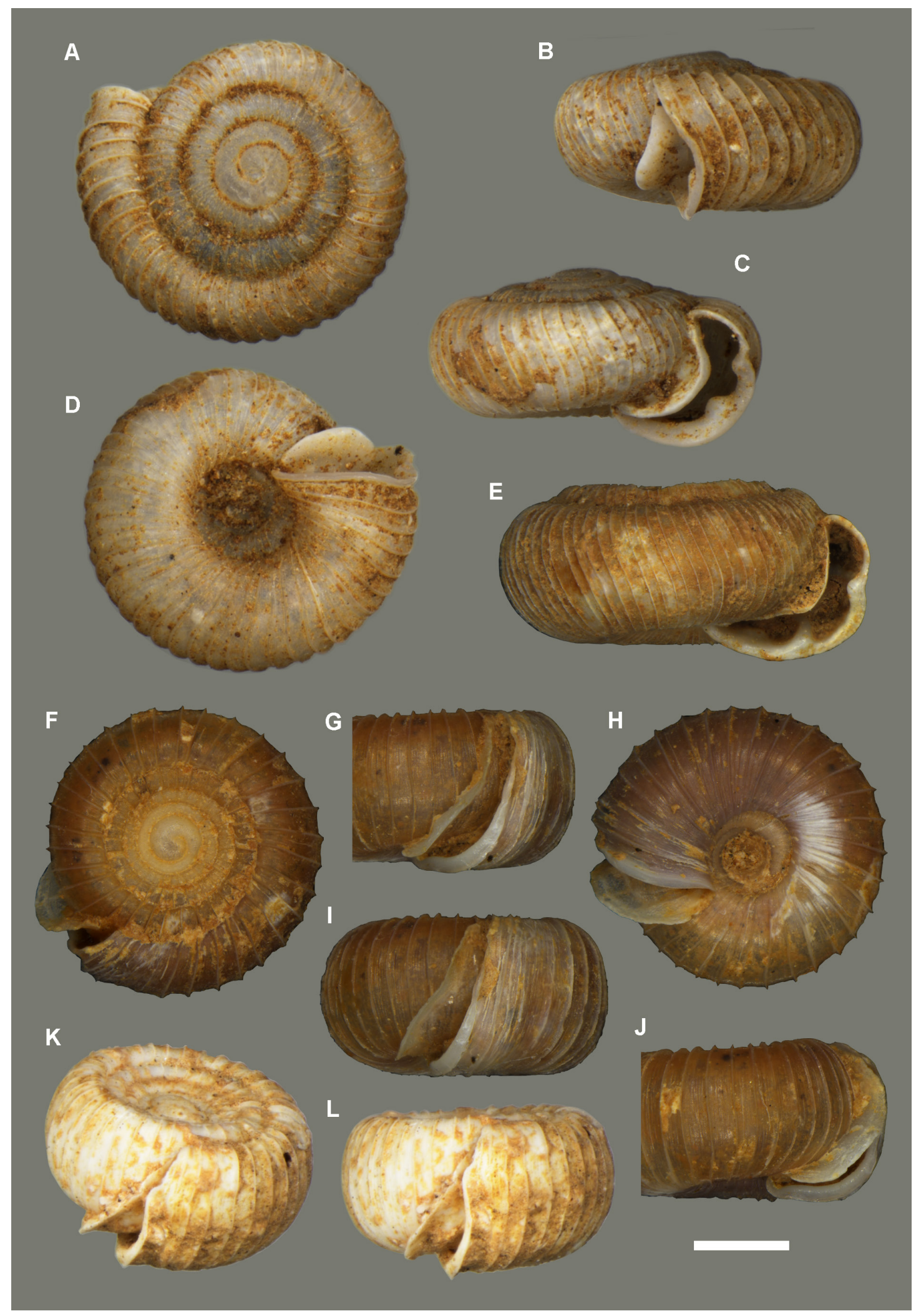

Fig. 3. Shells of species of Virpazaria Gittenberger, 1969. A-E. Virpazaria (Virpazaria) deelemanorum dhorai Reischütz et al., 2010. A-D. Holotype (NHMW 107224). E. Drisht (HNHM 103421). F-L. Virpazaria (Virpazaria) stojaspali Reischütz et al., 2009. F-J. Štegvaš Pass (HNHM 103441). K-L. Holotype (NHMW 106690). Scale bar $=1 \mathrm{~mm}$. 
FEHÉR Z. et al., Taxonomic revision of Virpazaria (Gastropoda, Spelaeodiscidae)

The occurrences are associated with three different bedrock types, namely Xhajë on Upper Jurassic and Drisht on Middle Triassic, whereas the two non-georeferenced sites east of Podgorica are probably on Upper Cretaceous limestone.

Virpazaria (Virpazaria) gittenbergeri Fehér \& Eröss sp. nov. urn:lsid:zoobank.org:act:C987B11A-418B-48B2-A5D5-B71966765600

Fig. 4A-E

Spelaeodiscus sp. (juv.) - Subai 2009: 111.

\section{Differential diagnosis}

This species can be distinguished from congeners by its small size and by its having one knob on the palatal peristome, and from species of the related Spelaeodiscus, which have one knob/tooth on the peristome by its inferiorly broader rounded body whorl and narrower aperture.

\section{Etymology}

This species is dedicated to and named after Edmund Gittenberger (Leiden, the Netherlands), a prominent malacologist who did pioneering work on the subterranean terrestrial gastropods of the Balkans. The name is used as the genitive of a noun of male gender.

\section{Material examined}

Holotype

MONTENEGRO - Rumija Mts, $2 \mathrm{~km} \mathrm{~S}$ of Štegvaš Pass on Ostros-Ulcinj road (4 km S of Arbnež); 42.0582 ${ }^{\circ}$ N, $19.3535^{\circ}$ E; 350 m alt.; 28 May 2015; T. Deli, Z. Erőss and Z. Fehér leg.; HNHM 103411.

\section{Paratypes}

MONTENEGRO • 20 spec.; same collection data as for holotype; HNHM 103413 - 20 spec.; same collection data as for holotype; NHMW $111671 \cdot 20$ spec., 38 fr.; same collection data as for holotype; DT $\bullet 8$ ad., 8 juv.; same locality as for holotype; 16 Jul. 2017; Z. Erőss and Z. Fehér leg.; HNHM 103451 - 8 ad., 9 juv.; same locality as for holotype; 16 Jul. 2017; Z. Erőss and Z. Fehér leg.; NHMW 111674 - 16 ad., 9 juv.; same locality as for holotype; 16 Jul. 2017; Z. Erőss and Z. Fehér leg.; ER • 2 ad., 1 juv.; SW of Štegvaš Pass, $2 \mathrm{~km} \mathrm{~S}$ of Arbnež on Ostros-Ulcinj road; $42.0636^{\circ} \mathrm{N}, 19.3710^{\circ} \mathrm{E}$; $480 \mathrm{~m}$ alt.; 16 Jul. 2017; Z. Erőss and Z. Fehér leg.; HNHM $103445 \cdot 3$ ad., 1 juv.; same collection data as for preceding; NHMW $111673 \cdot 3$ ad., 1 juv.; same collection data as for preceding; ER.

\section{Other material}

ALBANIA • Shkodër district, Mt Tarabosh, Vallas, near mosque; $42.0506^{\circ} \mathrm{N}, 19.4162^{\circ} \mathrm{E} ; 190 \mathrm{~m}$ alt.; 27 May 2015; T. Deli, Z. Erőss and Z. Fehér leg.; HNHM $103415 \bullet$ same collection data as for preceding; NHMW 110430/MN/0986 • same collection data as for preceding; DT.

\section{Dimensions}

Holotype: H 1.55 mm; W 2.5 mm; Ha 1.0 mm; Wa 1.1 mm. Paratypes (HNHM 103413, n=5): H 1.4-1.6 $\mathrm{mm}$; W 2.35-2.5 mm. Vallas population (HNHM 103415, n=5): H 1.25-1.5 mm; W 2.2-2.4 mm.

\section{Description}

Shell discoid, spire barely raised, consists of $4 \frac{1}{4}-43 / 4$ regularly increasing whorls, of which $1 \frac{1}{2}-2$ are protoconch whorls. Fresh shells glassy translucent, older shells whitish. Protoconch grained. Teleoconch whorls equidistantly ribbed: 59-69 ribs on body whorl and fine, regular lines in between. 


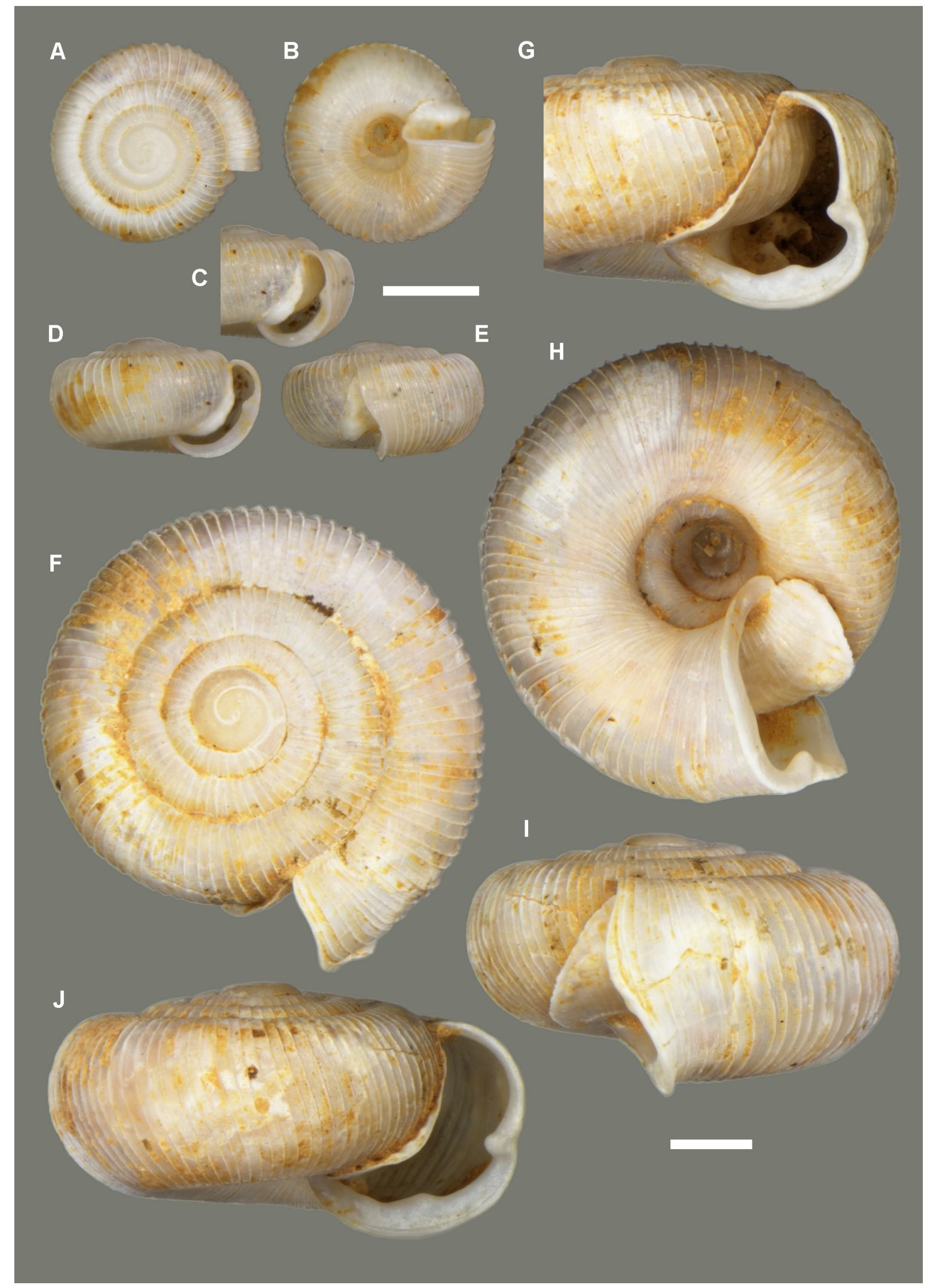

Fig. 4. Shells of species of Virpazaria Gittenberger, 1969. A-E. Virpazaria (Virpazaria) gittenbergeri Fehér \& Erőss sp. nov., holotype (HNHM 103411). F-J. Virpazaria (Virpazaria) pesici Fehér \& Deli sp. nov., holotype (HNHM 103403). Scale bars $=1 \mathrm{~mm}$ (note that the latter species is less magnified). 
FEHÉR Z. et al., Taxonomic revision of Virpazaria (Gastropoda, Spelaeodiscidae)

In bottom view, umbilicus wide, $1 / 4-1 / 5$ of total shell width, a small part of it overlaid by columellar part of aperture. In frontal view, silhouette of body whorl asymmetrically rounded (shouldered): broader curved in bottom, more angulated on upper side and near suture horizontally flattened. Suture barely depressed. Aperture narrow crescent-shaped. Instead of a flap, with an outstretched swelling (a thickened and emerged callus) on parietal side. One knob on palatal peristome, ca at one-third of way between its angular and columellar junctions. Peristome somewhat reflected between columellar junction and palatal knob, appearing thickened in frontal view. Above knob, peristome simple, delineating an apertural sinus. In side view, parietal swelling oblique (inferior part stands forward) and aperture sigmoidally inclined (inferior part stands backward).

\section{Distribution}

This species is known from the southeastern part of the Rumija Mts (also known as Mt Tarabosh). The Štegvaš Pass (Montenegro) and Vallas (Albania) populations are within a distance of $5 \mathrm{~km}$ of one another. Both sites are on Upper-Middle Triassic limestone. At the type locality, this species was found together with $V$. stojaspali and $V$. pesici.

\section{Conservation status}

To our present knowledge, this is a narrow-range endemic species with an area of occurrence (AOO) smaller than $20 \mathrm{~km}^{2}$. However, there is no reason to suppose that AOO, extent of occurrence (EOO), number of locations, number of subpopulations or the number of mature individuals are declining or extremely fluctuating. Therefore, it might be assessed as Near Threatened (NT).

\section{Remarks}

The Vallas population differs from the typical form by its denser ribbing ( $76-88$ ribs on the body whorl).

Virpazaria (Virpazaria) nicoleae Reischütz \& Reischütz, 2012

Fig. 5A-E

Virpazaria nicoleae A. Reischütz \& P.L. Reischütz, 2012: 17-18, 3 unnumbered figs.

\section{Diagnosis}

Small, shouldered, low conical shell, with conically raised spire, moderately wide umbilicus. Aperture crescent-shaped, most of it apart from sinus region covered by a strong, prominent parietal flap in frontal view. Callous thickening on peristome with a high palatal tooth, very strong basal tooth and an additional lower callous denticle between basal tooth and columellar insertion of peristome.

\section{Material examined}

Holotype

MONTENEGRO • 2 km S of Vitoja Spring, near Lake Skadar; Mar. 2010; Reischütz leg.; NHMW 108113

\section{Other material}

MONTENEGRO - Podgorica Municipality, $1 \mathrm{~km} \mathrm{~S}$ of Izvor Vitoja, near Lake Shkodra; $42.3196^{\circ} \mathrm{N}$, $19.3693^{\circ}$ E; 30 m alt.; 5 Jul. 2015; Erőss, Fehér and Grego leg.; HNHM 103425 • same collection data as for preceding; NHMW 110430/MN/0989.

\section{Dimensions}

H 1.7-1.9 mm; W 2.6-2.75 mm. 


\section{Distribution}

This species is known only from the type locality. The baserock where it was found is Lower Cretaceous (Neocomian) limestone.

Virpazaria (Virpazaria) pageti pageti Gittenberger, 1969

Fig. 5F-M

Virpazaria (Virpazaria) pageti Gittenberger, 1969: 301-302, fig. 6.

Virpazaria pageti alexanderi P.L. Reischütz \& Subai in Reischütz et al., 2012: 32, fig. 1.

Virpazaria (Virpazaria) pageti - Gittenberger 1988: 424. - Welter-Schultes 2012: 212, unnumbered fig. Virpazaria cf. pageti - Reischütz et al. 2011: 58, fig. 3.

Virpazaria pageti pageti - Reischütz et al. 2012: 33, fig. 3.

\section{Diagnosis}

Discoid shell, barely raised spire, body whorl silhouette rounded. Aperture narrow crescent-shaped. Peristome not thickened, without teeth or knobs. Parietal flap sharp-edged, directly connected with palatal peristome, detached from penultimate whorl (looks like a deformed tube).

\section{Material examined}

Holotype (V.pageti)

MONTENEGRO • "Bocche di Cattaro, Sutorina Mündung (Genist)" [Kotor Bay, in debris at mouth of Sutorina rivulet]; “Trissexodon Käufeli Typus”; Käufel leg.; NHMW-E 47864.

Holotype ( $V . p$. alexanderi)

CROATIA - Kotor Bay, Prevlaka Peninsula, near Prevlaka Village, between Osti rt and border station at Njivice; Mar. 2010; A., N. and P.L. Reischütz leg.; NHMW 108106.

Paratypes $(V \cdot$ pageti)

MONTENEGRO • 1 spec.; same collection data as for holotype; NHMW-E 47864a.

Paratypes (V.p. alexanderi)

CROATIA • 1 spec.; same collection data as for holotype; NMBE 539847 • 2 ad., 15 juv.; Reischütz private collection [not seen].

\section{Other material}

CROATIA - Prevlaka Peninsula, $1.5 \mathrm{~km}$ from Croatian border station to Fort Prevlaka; $42.4181^{\circ} \mathrm{N}$, $18.5132^{\circ} \mathrm{E}[\approx$ type locality of $V$. alexanderi $] ; 60 \mathrm{~m}$ alt.; 17 Jul. 2018; Z. Erőss, T. Fehér and Z. Fehér leg.; HNHM 104391.

MONTENEGRO - Igalo, W of Herceg Novi, S of Sutorina-Njivice-Igalo junction, limestone rock cavity; 19 Sep. 2005; P. Subai leg.; HNHM 102250 • Prevlaka Peninsula, Igalo (near Herceg-Novi), $\mathrm{W}$ side of bay at Žvinje junction; $42.4455^{\circ} \mathrm{N}, 18.5050^{\circ} \mathrm{E}$; $50 \mathrm{~m}$ alt.; 29 May 2015; T. Deli, Z. Erőss and Z. Fehér leg.; HNHM 103427 • same collection data as for preceding; NHMW 110430/MN/0990 • beneath Žvinje on serpentine road; $42.4460^{\circ} \mathrm{N}, 18.5029^{\circ} \mathrm{E} ; 160 \mathrm{~m}$ alt.; $17 \mathrm{Jul}$. 2018; Z. Erőss, T. Fehér and Z. Fehér leg.; HNHM $104390 \cdot$ Njivice, ca $2 \mathrm{~km}$ from Igalo junction; $42.4316^{\circ} \mathrm{N}, 18.5170^{\circ} \mathrm{E}$; $60 \mathrm{~m}$ alt.; 18 Jul. 2017; Z. Eröss and Z. Fehér leg.; HNHM 104395.

\section{Dimensions}

H 1.3-1.9 mm; W 2.1-3.2 mm. 
FEHÉR Z. et al., Taxonomic revision of Virpazaria (Gastropoda, Spelaeodiscidae)

Virpazaria (Virpazaria) pageti kleteckii Štamol \& Subai in Reischütz et al., 2012

Virpazaria pageti kleteckii Štamol \& Subai in Reischütz et al., 2012: 32, fig. 2.

\section{Diagnosis}

Distinguished from nominate form by smaller, non-detached aperture, which is less covered by parietal flap in frontal view.

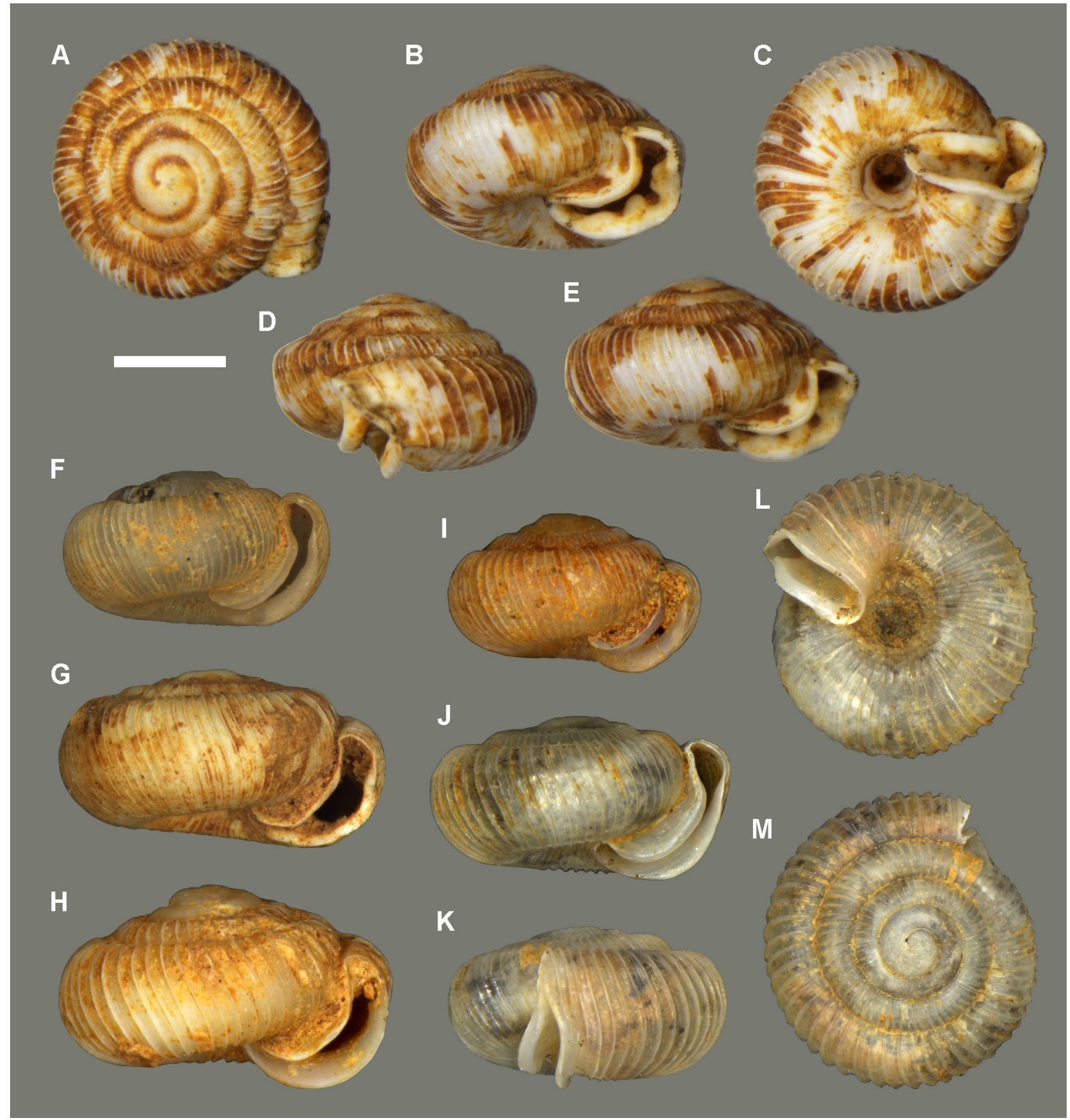

Fig. 5. Shells of species of Virpazaria Gittenberger, 1969. A-E. Virpazaria (Virpazaria) nicoleae Reischütz \& Reischütz, 2012, holotype (NHMW 108113). F-M. Virpazaria (Virpazaria) pageti Gittenberger, 1969. F-I. Between Fort Prevlaka and the border station (HNHM 104391). J-M. Igalo (HNHM 102250). Scale bar $=1 \mathrm{~mm}$. 


\section{Material examined}

Holotype

CROATIA • Konavle Region, Gruda, Vilina Cave; UTM: BN81; 6 Apr. 2010; R. Ozimec leg.; CNHM 10393.

\section{Paratypes}

CROATIA $\bullet 2$ spec.; same collection data as for holotype; Croatian Biospeleological Society collection [not seen] • 1 spec.; in Dubravka village, ca 5 km NE of Gruda; Mar. 2011; A. and P.L. Reischütz leg.; Reischütz private collection [not seen].

\section{Dimensions}

H $1.5-1.65 \mathrm{~mm}$; W $2.75-3.0 \mathrm{~mm}$.

\section{Distribution and remarks}

This species (including its subspecies) has a restricted range north of Kotor Bay in Croatia and Montenegro (Gittenberger 1969; Reischütz et al. 2012). The type lot of the nominate form was collected from debris at the mouth of the Sutorina River. Later, this species was found in rock crevices at the eastern side of Prevlaka Peninsula, between Njivice and Igalo very near the type locality (see Gittenberger 1988). At another point of the Prevlaka, ca $3.5 \mathrm{~km}$ as the crow flies from the former site, Reischütz et al. (2012) reported further shells of this species (four adults and 15 juveniles). They were distinguished from the nominate form by their smaller shell, finer and denser ribbing, smaller parietal flap, as well as the nondetached aperture, and were described as Virpazaria pageti alexanderi. In 2018, we were able to obtain a larger sample of $V$. p. alexanderi from the type locality that provided a good opportunity to study size extremes and the variability of character states within this population. In our sample (HNHM 104391), shell width ranged between 2.1 and $3.0 \mathrm{~mm}$, shell height between 1.3 and $1.9 \mathrm{~mm}$, number of whorls between $33 / 4$ and $4 \frac{1}{4}$, number of ribs on the last whorl between 48 and 83 and we found specimens with detached and non-detached apertures as well. The values and character states given by Gittenberger (1988) for the nominate form and those given by Reischütz et al. (2012) for V. p. alexanderi all fall within these ranges. This alone might be a good reason for treating them as synonyms, which is only reinforced once their geographical distribution is also taken into consideration. The two type localities are not only close to each other, but are located along the foot of the same limestone hill, which is composed of the same Upper Cretaceous geological formation. Having no geographical or geological barrier in between, it is likely that the two sites contain the same subterranean population and an extensive sampling along the Prevlaka Peninsula might detect this species at further locations.

Virpazaria pageti kleteckii was found at two locations somewhat north of the Prevlaka; namely at Vilina Spilja near Gruda and at Dubravka ca $5 \mathrm{~km} \mathrm{NE}$ of Gruda. The original description was based on four specimens only (three from Vilina Spilja and one from Dubravka). Until further available material makes it possible to test the stability of distinguishing features, $V . p$. kleteckii must be accepted as a distinct subspecies.

Virpazaria (Virpazaria) pesici Fehér \& Deli sp. nov. urn:1sid:zoobank.org:act:248898E8-C732-44A5-A599-620ACC478962

Fig. 4F-J

\section{Differential diagnosis}

This species can be distinguished from all congeners by its large size; additionally, from V. deelemanorum, which also has two knobs on the peristome, by the smaller knobs and more reduced parietal flap; from 
Spelaeodiscus unidentatus Bole, 1961 and S. albanicus (A.J. Wagner, 1914), which have small knobs on their peristome, by the crescent-shaped aperture and the presence of a parietal flap.

\section{Etymology}

This species is dedicated to and named after Vladimir Pešić (Podgorica, Montenegro) a prominent acarologist and hydrobiologist who significantly contributed to our knowledge of the mollusc fauna of Montenegro. The name is used as the genitive of a noun of male gender.

\section{Material examined}

\section{Holotype}

MONTENEGRO - Rumija Mts., 2 km S of Štegvaš Pass on Ostros-Ulcinj road, 4 km S of Arbnež; $42.0582^{\circ}$ N, $19.3535^{\circ}$ E; 350 m alt.; 28 May 2015; T. Deli, Z. Erőss and Z. Fehér leg.; HNHM 103403.

\section{Paratypes}

MONTENEGRO • 30 ad., 20 fr.; same collection data as for holotype; HNHM 103405 • 23 ad., 18 fr.; same collection data as for holotype; NHMW $111668 \cdot 32$ ad., $32 \mathrm{fr}$.; same collection data as for holotype; DT • 3 fr.; same locality as for holotype; 16 Jul. 2017; Z. Erőss and Z. Fehér leg.; ER • 1 fr.; SW of Štegvaš Pass, 2 km S of Arbnež on Ostros-Ulcinj road; $42.0636^{\circ} \mathrm{N}, 19.3710^{\circ} \mathrm{E} ; 480 \mathrm{~m}$ alt.; 16 Jul. 2017; Z. Erőss and Z. Fehér leg.; HNHM 103407 • 1 fr.; same collection data as for preceding; NHMW $111669 \bullet 2$ fr.; same collection data as for preceding; ER • 1 spec.; $2 \mathrm{~km} \mathrm{~S}$ of Donji Murići junction on Virpazar-Ostros road; $42.1424^{\circ} \mathrm{N}, 19.2197^{\circ} \mathrm{E}$; $320 \mathrm{~m}$ alt.; 16 Jul. 2017; Z. Erőss and Z. Fehér leg.; HNHM 103409• 1 spec.; same collection data as for preceding; NHMW $111670 \bullet 2$ spec.; same collection data as for preceding; ER.

\section{Dimensions}

Holotype: H 3.15 mm; W 5.8 mm; Ha 2.65 mm; Wa 2.7 mm. Paratypes (HNHM 103405, n=10): H 3.0-3.3 mm; W 5.1-6.0 mm.

\section{Description}

Shell discoid, spire barely raised, consisting of $4 \frac{2}{3}-5$ regularly increasing whorls, of which $1 \frac{1}{2}-1 \frac{3}{4}$ are protoconch whorls. Protoconch smooth. Teleoconch whorls densely and equidistantly ribbed (91-110 ribs on last whorl), no riblets, only some irregular and indistinct lines visible between ribs at $50 \times$ magnification.

In bottom view, umbilicus wide, $1 / 4$ of total shell width, a small part of it overlayed by columellar part of aperture. In frontal view, silhouette of body whorl more or less regularly rounded: bottom side slightly broader curved. Suture slightly but perceptibly depressed. Aperture crescent-shaped, parietal flap small, thin and weakly attached to shell (often missing from weathered old shells). Two knobs on peristome: a wider basal and a higher (rather tooth-like) palatal. Palatal knob situated somewhat lower than one-third way between angular and columellar junctions of peristome. Peristome somewhat reflected between columellar junction and palatal knob, appearing thickened in frontal view. Above palatal knob, peristome simple. In side view, parietal flap oblique (inferior part stands forward) and aperture sigmoidally inclined (inferior part stands backward).

\section{Distribution}

So far, this species has only been found on the southern side beneath Štegvaš Pass in the Rumija Mts, on Upper-Middle Triassic limestone. It was found there together with $V$. stojaspali and $V$. gittenbergeri sp. nov. 


\section{Conservation status}

To our present knowledge this species is very rare, all known records belonging to the same subpopulation and AOO is smaller than $20 \mathrm{~km}^{2}$. At the same time, there is no reason to suppose that AOO, EOO, number of locations, number of subpopulations or the number of mature individuals are declining or extremely fluctuating. Therefore, it might be assessed as Near Threatened (NT).

Virpazaria (Virpazaria) stojaspali Reischütz et al., 2009

Fig. 3F-L

Virpazaria stojaspali A. Reischütz, P.L. Reischütz \& Subai in A. Reischütz \& P.L. Reischütz 2009: 58, figs 6-7.

Virpazaria stojaspali - Subai 2009: 109, fig. 10. - Welter-Schultes 2012: 212 (in part).

\section{Diagnosis}

Disc-shaped shell, entirely flat on topside. Protoconch relatively large and somewhat prominent. Body whorl silhouette shouldered, umbilicus wide. Aperture very narrow crescent-shaped, entirely covered by a parietal flap in frontal view. Peristome thickened, without knobs.

\section{Material examined}

Holotype

MONTENEGRO - Rumija Mts, rocks above Bes; Jul. 2008; A. Reischütz, N. Reischütz and P.L. Reischütz leg.; NHMW 106690.

\section{Paratypes}

MONTENEGRO - 1 spec.; Mt. Kroništar, S slope, approx. $10 \mathrm{~km} \mathrm{E} \mathrm{of} \mathrm{Đuravci,} \mathrm{in} \mathrm{direction} \mathrm{to} \mathrm{Ostros,}$ S of Lake Skadar; 350 m alt.; 21 Sep. 2005; P. Subai leg.; SMF 333502 • 29 spec.; same collection data as for preceding; NMBE 539839 • 1 spec.; same locality as for preceding; 16 Sep. 2006; P. Subai leg.; HNHM $96784 \bullet 26$ spec.; same collection data as for preceding; NMBE $539838 \bullet 4$ spec.; near preceding locality, on W slope; 26 Sep. 2006; P. Subai and M. Szekeres leg.; NMBE 539840.

\section{Other material}

MONTENEGRO - Donji Murići, above village, at junction of a minor road to Besa; $42.1539^{\circ} \mathrm{N}$, 19.2155 E E; 200 m alt.; 16 Jul. 2017; Z. Eröss and Z. Fehér leg.; HNHM 103443 • Besa, Krone i Besit, $2 \mathrm{~km} \mathrm{~S}$ of Donji Murići junction on Virpazar-Ostros road; $42.1424^{\circ} \mathrm{N}, 19.2197^{\circ} \mathrm{E} ; 320 \mathrm{~m}$ alt.; 16 Jul. 2017; Z. Erőss and Z. Fehér leg.; HNHM 103216 • same locality as for preceding; 19 Oct. 2017; T. Deli, Z. Eröss, A. Hunyadi and B. Páll-Gergely leg.; DT • same collection data as for preceding; ER • SE of Virpazar, $7.3 \mathrm{~km} \mathrm{~S}$ (SE) of Đuravci, $1.6 \mathrm{~km} \mathrm{NNW}$ of Tejani; $42.1134^{\circ} \mathrm{N}, 19.2231^{\circ} \mathrm{E} ; 455 \mathrm{~m}$ alt.; 19 Oct. 2017; T. Deli, Z. Erőss, A. Hunyadi and B. Páll-Gergely leg.; DT • same collection data as for preceding; ER - Rumija Mts, $2 \mathrm{~km} \mathrm{~S}$ of Arbnež, on Ostros-Ulcinj road, SW of Štegvaš Pass; $42.0636^{\circ} \mathrm{N}, 19.3710^{\circ} \mathrm{E} ; 480 \mathrm{~m}$ alt.; 16 Jul. 2017; Z. Erőss and Z. Fehér leg.; HNHM 103447 • Rumija Mts, $4 \mathrm{~km} \mathrm{~S}$ of Arbnež, on Ostros-Ulcinj road, $2 \mathrm{~km} \mathrm{~S}$ of Štegvaš Pass; $42.0582^{\circ} \mathrm{N}, 19.3535^{\circ} \mathrm{E}$; 350 m alt.; 28 May 2015; T. Deli, Z. Erőss and Z. Fehér leg.; HNHM 103441 • same collection data as for preceding; NHMW 110430/MN/0997 • same locality as for preceding; 16 Jul. 2017; Z. Eröss and Z. Fehér leg.; HNHM 103449.

\section{Dimensions}

H 1.7-2.0 mm; W 2.8-3.3 mm. 


\section{Distribution}

This species lives in the Rumija Mts west of Lake Skadar. Type material came from two locations (Reischütz \& Reischütz 2009; Subai 2009), but none of them were georeferenced. Our findings extend the known species range and reveal its co-occurrence with three congeneric species, namely $V$. aspectulabeatidis, $V$. gittenbergeri sp. nov. and $V$. pesici sp. nov. The georeferenced occurrences are from Upper-Middle Triassic and from Upper-Middle Jurassic limestone.

\section{Remarks}

Referring to alleged morphological similarity, Welter-Schultes (2012) claimed that this species might be a junior synonym of $V$. adrianae Gittenberger, 1969. In our opinion, the shapes of the shells of these two species are totally different; $V$. stojaspali is the only known species of Virpazaria with an entirely flat topside. Furthermore, the apertures are also very different, with three knobs in $V$. adrianae and without any knobs in $V$. stojaspali.

Virpazaria (Aemiliella) ripkeni ripkeni Gittenberger, 1969

Fig. 6A-L

Virpazaria (Aemiliella) ripkeni Gittenberger, 1969: 302-303, fig. 7.

Virpazaria (Aemiliella) pastorpueri A. Reischütz, N. Reischütz \& P. L. Reischütz, 2011: 57, figs 1-2.

Virpazaria (Aemiliella) ripkeni - Welter-Schultes 2012: 212.

Virpazaria (Aemiliella) ripkeni pastorpueri-Gittenberger 2015: 24, figs 3-4.

\section{Diagnosis}

Discoid shell, somewhat raised spire. Crescent-shaped aperture, thin but prominent parietal flap. Except for sinus area entire peristome thickened, with three protrusions: upper one is external end of palatal lamella, which reaches deeply inside (more than $1 / 10$ of a whorl) and melts into a callous structure (which is often non-parallel with palatal lamella); middle one is external end of basal lamella, which reaches deeply inside (more than $1 / 10$ of a whorl); lower one is a small denticle at half way between columellar insertion and basal lamella.

\section{Material examined}

Holotype (V. ripkeni)

MONTENEGRO • "Soko Höhle bei Dupilo westl. von Virpazar, Jugosl." [W of Virpazar, Velika Jama, at Mt Soko near Dupilo = same type locality as for $V$. adrianae, but see Remarks]; NHMW 77153.

Holotype (V. pastorpueri)

ALBANIA • Drisht, small cave beneath ruins of Drisht; Jul. 2010; A. Reischütz, N. Reischütz and P.L. Reischütz leg.; NHMW 107855.

Paratypes (V. ripkeni)

MONTENEGRO • 6 spec.; same collection data as for holotype; "Trissexodon kusceri Montenegro Pečina Grbočica bei Virpazar"[original Edlauer label]; NHMW 77153a • 1 spec.; same collection data as for holotype; RMNH 53302.

Paratypes ( $V$. pastorpueri)

ALBANIA • $1 \mathrm{spec}$.; same collection data as for holotype; NMBE $539850 \bullet$ further spec.; same collection data as for holotype; Reischütz collection [not seen]. 


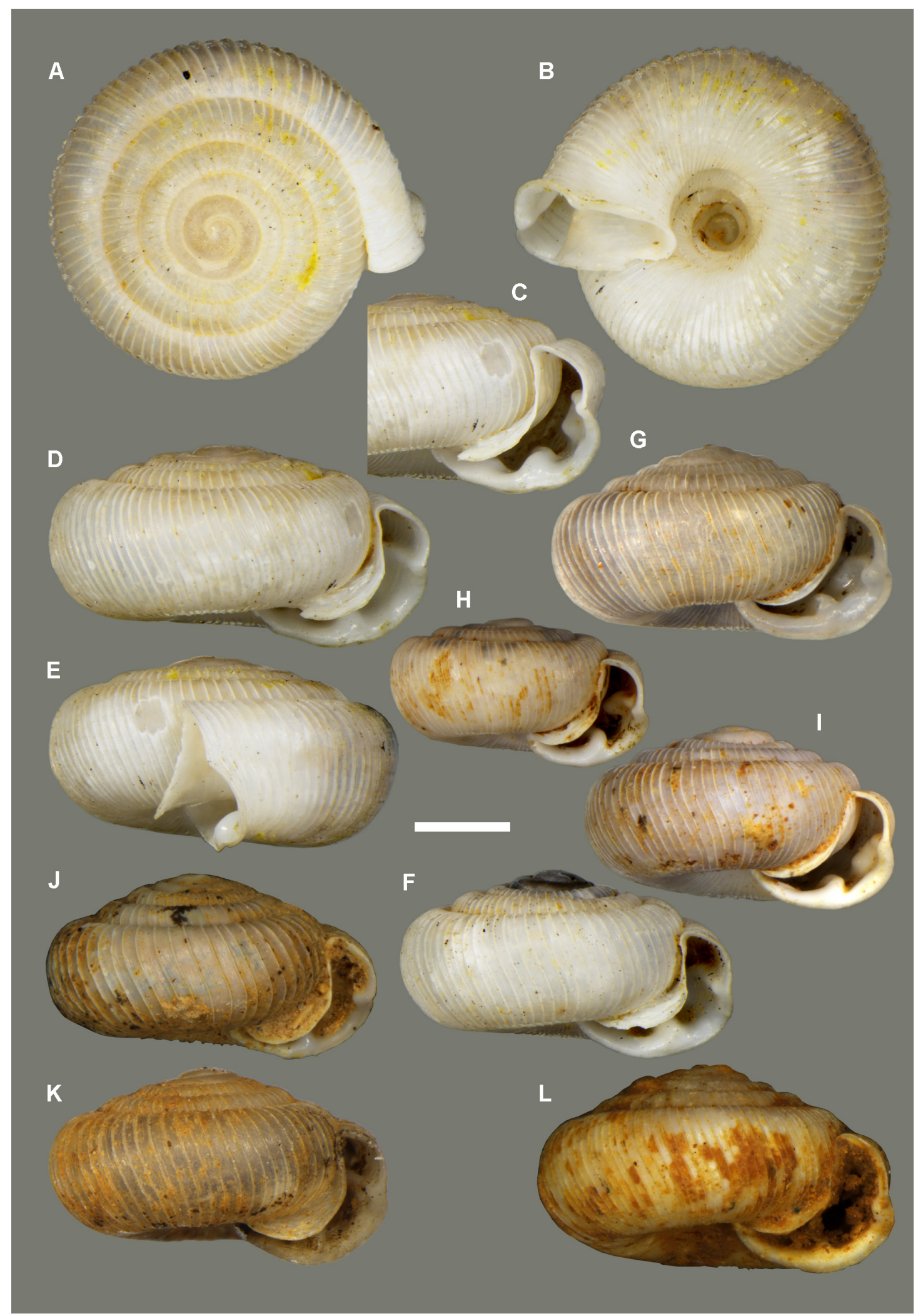

Fig. 6. Shells of Virpazaria (Aemiliella) ripkeni Gittenberger, 1969. A-E. Holotype (NHMW 77153). F. Paratype (NHMW 77153a). G. Malkolaj (HNHM 103437). H-I. Gadoc (HNHM 103429). J. Drisht (HNHM 104392). K. Holotype of $V$. pastorpueri Reischütz et al., 2011 (NHMW 107855). L. Kruni i Baksit (HNHM 103433). Scale bar $=1 \mathrm{~mm}$. 
FEHÉR Z. et al., Taxonomic revision of Virpazaria (Gastropoda, Spelaeodiscidae)

\section{Other material}

ALBANIA - Shkodër District, Gadoc, on Velipojë-Baks-Rjollë road, near Kruni i Gadocit; 41.8980 N ${ }^{\circ}$ 19.4425 ${ }^{\circ}$ E; 3 m alt.; 27 May 2015; T. Deli, Z. Erőss and Z. Fehér leg.; HNHM 103429 • same collection data as for preceding; NHMW 110430/MN/0991 $2 \mathrm{~km} \mathrm{~W}$ of Baks-Rjollë, on road to Velipojë; $41.8763^{\circ} \mathrm{N}, 19.4592^{\circ} \mathrm{E} ; 10 \mathrm{~m}$ alt.; 28 May 2015; T. Deli, Z. Erőss and Z. Fehér leg.; HNHM $103431 \cdot$ same collection data as for preceding; NHMW 110430/MN/0992 • $3 \mathrm{~km} \mathrm{~W}$ of Baks-Rjollë, Kruni i Baksit; $41.8831^{\circ} \mathrm{N}, 19.4533^{\circ}$ E; $5 \mathrm{~m}$ alt.; 28 May 2015; T. Deli, Z. Erőss and Z. Fehér leg.; HNHM 103433 • same collection data as for preceding; NHMW 110430/MN/0993 • Qafë Shtiqë (Renc Mt), on Shkodër-Velipojë road; $41.9161^{\circ} \mathrm{N}, 19.4268^{\circ} \mathrm{E}$; $50 \mathrm{~m}$ alt.; 28 May 2015; T. Deli, Z. Eröss and Z. Fehér leg.; HNHM 103435 • same collection data as for preceding; NHMW 110430/MN/0994 - Malkolaj, at Torovicë junction on Shkodër-Velipojë road; $41.9270^{\circ} \mathrm{N}, 19.4387^{\circ}$ E; 2 m alt.; 28 May 2015; T. Deli, Z. Erőss and Z. Fehér leg.; HNHM 103437 • same collection data as for preceding; NHMW 110430/MN/0995 - Shkodër District, Drisht, E slope of Kalaja e Drishtit [type locality of V. pastorpueri]; $42.1248^{\circ} \mathrm{N}, 19.6150^{\circ} \mathrm{E} ; 190 \mathrm{~m}$ alt.; 4 Jul. 2015; Z. Erőss, Z. Fehér and J. Grego leg.; HNHM 103439 • same collection data as for preceding; NHMW 110430/MN/0996 • Drisht, right bank of Kiri River at Shpellë Korbe; $42.1250^{\circ}$ N, $19.6031^{\circ}$ E; 90 m alt.; 14 Jul. 2018; T. Fehér, Z. Fehér and R. Lika leg.; HNHM 104392.

MONTENEGRO • 1 spec.; same collection data as for holotype; "Albanien Velika Jama bei Soko Dupilo Umgebung von Virpazar lg. Dabović Trissexodon kusceri n. sp. Smmlg. Edlauer 57441", "Innenfallen der Außenwand der Mündung Virpazar, Smmlg. Edlauer"[original Edlauer labels]; on label indicated as paratype; NHMW 77154.

\section{Dimensions}

H 1.5-2.25 mm; W 2.7-4.0 mm (see Remarks for $V$. (A.) r. arbeni).

Virpazaria (Aemiliella) ripkeni arbeni Gittenberger, 2015

Virpazaria (Aemiliella) ripkeni arbeni Gittenberger, 2015: 27, fig. 8.

\section{Diagnosis}

The upper palatal lamella which does not or hardly reaches the peristome and the non-thickened, knobless peristome are the features that distinguish this subspecies from the nominate subspecies.

\section{Material examined}

\section{Holotype}

ALBANIA • Shkodër, Rozafa Cave [= Shpella e Rozafës]; $42.0487^{\circ}$ N, $19.4938^{\circ}$ E; 18 Oct. 2011; E. Gittenberger leg.; RMNH 5003974 [not seen].

\section{Paratypes}

ALBANIA • 2 spec.; same locality as for holotype; May 2013; M. Slooff leg.; RMNH 5003975 [not seen].

\section{Dimensions}

H 1.7-1.8 mm; W 3.1-3.2 mm (based on three specimens according to Gittenberger 2015).

\section{Distribution}

Recent records of this species are from the southern rim of the Shkodër Lake Basin, from the surroundings of Shkodër. The Shkodër site is located on Upper Triassic, the Drisht site on Middle Triassic and the 
Renc Mts site on Upper Cretaceous limestone. If these were the only known localities, this would already make $V$. ripkeni the widest distributed species of its genus. Strangely, the type locality of the nominate subspecies is located at the northwestern side of the Shkodër Lake Basin, very far from these Albanian sites (but see Remarks).

\section{Remarks}

This species was described on the basis of eight specimens. Their width and height are $3.5-4.0 \mathrm{~mm}$ and $2.05-2.25 \mathrm{~mm}$, respectively, and the number of ribs on the last whorl is 73-86. In the original description (Gittenberger 1969) somewhat lower values were given, probably because he applied a different measuring method. The holotype of $V$. pastorpueri is $3.6 \mathrm{~mm}$ wide and $2.15 \mathrm{~mm}$ high with 60 ribs on its last whorl (although Reischütz et al. (2011) provided a smaller width (3.0-3.5 mm), a larger height $(2.5 \mathrm{~mm})$ and an average of 65 ribs on the last whorl). Smaller and more tapered shells were defined by Reischütz et al. (2011) as the most important features to distinguish $V$. pastorpueri from V. ripkeni. Later, Gittenberger (2015) studied a larger series of topotypical V. pastorpueri specimens and concluded that their shells are neither smaller nor relatively higher and thicker discoid than those of typical $V$. ripkeni. However, he found that the ribbing of $V$. pastorpueri is less dense (less than 70 ribs on the last whorl) and therefore he preserved it as a distinct subspecies, V. ripkeni pastorpueri. In the same paper, Gittenberger described another subspecies, V. ripkeni arbeni, which is smaller $(\mathrm{H} 1.7-1.8 \mathrm{~mm}$; W 3.0-3.1 mm) and has a weakly developed peristome.

We collected several hundred specimens of this species at four different locations in the Renc Mts. Their shell width ranges between 2.7 and $3.6 \mathrm{~mm}$, shell height between 1.5 and $2.1 \mathrm{~mm}$ and the number of ribs on the last whorl between 60 and 82. Compared to topotypical V. pastorpueri, their size, shape and rib density values largely overlap. Although one might say that they are generally somewhat smaller and more tapered than typical $V$. ripkeni, neither these characters nor the rib density are able to provide a clear-cut distinction. This large variability in rib density refutes Gittenberger's argument (Gittenberger 2015), and makes any distinction between $V$. pastorpueri and $V$. ripkeni meaningless. However, none of the many adult specimens from the Renc Mts have such a weakly developed peristome as in the three specimens that were described as $V$. ripkeni arbeni. Having no more material available from the type locality of $V$. $r$. arbeni (Shkodër), it is not possible to test whether the entire population consistently has an underdeveloped peristome there or the subspecies was described on the basis of three freak individuals. Until this question is settled, we must preserve $V$. ripkeni arbeni.

The type material of V. ripkeni was presumably collected by Petar Dabovic in the 1930s, passed somehow to the Viennese private collector Aemilian Edlauer, and finally landed in the NHMW Mollusc Collection. It appears that Edlauer, or someone else who studied his collection, recognized, but never described, three different species of Virpazaria. The proposed names were 'Trissexodon kuščeri', 'Trissexodon montenegrina' and 'Trissexodon Käufeli'. The latter name was obviously proposed for $V$. pageti, but the situation is more dubious with the other two. Among the lots of $V$. adrianae we could find both 'Trissexodon kuščeri' and 'Trissexodon montenegrina' labels, whereas the name 'Trissexodon kuščeri' also appears in the material of $V$. ripkeni. Gittenberger (1969) mentioned eight type specimens of $V$. ripkeni from the same original lot (of which one was designated as a holotype, one made its way to the RMNH and six remained in the original vial and kept the original labels (NHMW 77153a)). Interestingly, another site, "Pečina Grbočica bei Virpazar", is indicated on the original label in that vial, whereas "Soko Höhle bei Dupilo", which is given in the description, can be found on a newer label written in someone else's handwriting. Furthermore, there is another lot (NHMW 77154), which is from Soko Cave according to the original label and contains one specimen of $V$. ripkeni, but not mentioned by Gittenberger (1969). Even stranger, this lot contains an original Edlauer label with the same locality, the same voucher number (E-57441) and the same proposed name, 'Trissexodon kusceri', as the type lot of 
V. adrianae. It seems very difficult, if not impossible, to trace back whether there was any mixup with the labels or the specimens in the past, and, if so, where exactly the type specimens of $V$. ripkeni came from (Soko?, Grbočica? or from somewhere else?). The fact that neither Gittenberger (1975) nor anyone else has been able to refind $V$. ripkeni at its alleged type locality or anywhere else in the Virpazar area further discredits the validity of the type locality.

\section{Discussion}

Species of Virpazaria inhabit the karstic hills surrounding the basin of Lake Shkodër and a small isolated spot in the coastal foothills of the Orjen Mts at the northern part of Kotor Bay. This narrow-range genus comprises ten narrow-range species.

In this paper, we describe two of them as new and also propose the synonymization of $V$. ripkeni pastorpueri and V. pageti alexanderi with their nominate forms. At the time of their description, based on the knowledge at that time, they fulfilled the requirements to consider them subspecies, i.e., they seemed to occupy distinct geographic ranges and they seemed to have distinct morphological character(s). Now, however, available new distribution records and larger samples allow us to see them in a new light. Now we know that the intra-population variability of the features believed to be important for subspecific distinction in $V$. ripkeni and $V$. pageti (shell size, shell shape, rib density) is far larger than the interpopulation differences. At the same time, we did not change the status of three other subspecies, namely $V$. deelemanorum dhorai, $V$. pageti kleteckii and $V$. ripkeni arbeni, more because we do not have enough data than because we are convinced of their distinct status. Since the genus Virpazaria is far from well explored, it can be assumed that after more intense sampling, new populations will be discovered and more material will be available in the future. This will hopefully provide a better foundation on which to test and reevaluate the taxonomic status of the three aforementioned subspecies.

Virpazaria is obviously bound to karstic areas, but we could not discover any preference in terms of the type or age of the limestone baserock. Usually, one species of Virpazaria is found at a given location, but there are cases when two or three congeners have been found to co-occur. The associated fauna frequently includes other MSS-specific species of Platyla, Vitrea and Gyralina, and occasionally Pholeotheras euthrix and species of Spelaeodiscus, Klemmia and Agardhiella as well.

Generally speaking, there were two different types of (not always easily distinguishable) micro-habitats where we sampled: (i) holes that are probably terminal caverns, with clearly visible signs of dissolution of the rock by water and (ii) fissures or cracks in the rock formed mechanically and filled with a deposit of particulate matter. At the moment we still have too few data to draw far-reaching conclusions, but we had the impression during our field work that Virpazaria prefers the former, whereas Agardhiella and Spelaeodiscus prefer the latter type of micro-habitat. This might be a potential explanation of why they cannot be found more often syntopically; however, this idea needs to be statistically tested on a larger dataset (as in Fehér et al. 2018).

\section{Acknowledgements}

We are grateful to Anita Eschner (NHMW) and Sigrid Hof (SMF) for allowing access to the museum collections in their care, to Eike Neubert (NMBE) for loaning shells for examination, to Nesrine Akkari (NHMW) for her help in photographing shells, and to Alexander Reischütz, Edmund Gittenberger and an anonymous reviewer for their constructive and helpful review comments. Tamás Fehér, Jozef Grego, András Hunyadi, Barna Páll-Gergely and Miklós Szekeres helped during field trips and Péter Subai provided inspiration and important information about collecting methods. This study was supported by a grant from the Austrian Science Fund (FWF P- 26581-B25) to Z. Fehér. 


\section{References}

Arndt E. \& Subai P. 2013. Gastropoda from subterranean habitats in Greece. Vernate 31/2012: 213-224.

Bole J. 1965. Die Vertreter der Gattung Spelaeodiscus Brusina 1886 (Gastropoda, Pulmonata) in Jugoslawien. International Journal of Speleology 1 (3): 349-356.

https://doi.org/10.5038/1827-806X.1.3.9

Camacho A.I. 1992. The Natural History of Biospeleology. Monografias del M.N.C.N. 7. CSIC, Madrid.

Culver D.C. \& Pipan T. 2014. Shallow Subterranean Habitats. Oxford University Press, Oxford.

Fehér Z., Mason K., Szekeres M., Haring E., Bamberger S., Páll-Gergely B. \& Sólymos P. 2018. Range-constrained co-occurrence simulation reveals little niche partitioning among rock-dwelling Montenegrina land snails (Gastropoda: Clausiliidae). Journal of Biogeography 45 (6): 1444-1457. https://doi.org/10.1111/jbi.13220

Gittenberger E. 1969. Beiträge zur Kenntnis der Pupillacea. I. Die Spelaeodiscinae. Zoologische Mededelingen 43 (22): 287-306.

Gittenberger E. 1975. Beiträge zur Kenntnis der Pupillacea. V. Die Spelaeodiscinae, erster Nachtrag. Zoologische Mededelingen 48 (23): 263-277.

Gittenberger E. 1988. Über Virpazaria (V.) pageti Gittenberger 1969, Gyralina (G.) pageti n. sp. und deren Sekundärfundorte (Mollusca: Pulmonata). Annalen des Naturhistorischen Museums in Wien 90B: 423-426.

Gittenberger E. 2015. Caving for snails in northern Albania. Basteria 79 (1-3): 23-29.

Hudec V. 1965. Neue Erkenntnisse über den Geschlechtsapparat von Argna bielzi (Rossmässler) und Bemerkungen zur systematischen Stellung der Gattung Argna. Archiv für Molluskenkunde 94: 157-165.

Juberthie C., Delay B. \& Bouillon M. 1980. Sur l'existence du milieu souterrain superficiel en zone non calcaire. Comptes Rendus de l'Académie des Sciences de la France D 290: 49-52.

Juberthie C.B., Delay B. \& Bouillon M. 1981. Sur l'existence d'un milieu souterrain superficiel en zone calcaire. Mémoires de Biospéologie 8: 77-93.

Kerney M.P. \& Cameron R.A.D. 1979. A Field Guide to the Land Snails of Britain and North-West Europe. Collins, London.

Mammola S., Giachino P.M., Piano E., Jones A., Barberis M., Badino G. \& Isaia M. 2016. Ecology and sampling techniques of an understudied subterranean habitat: the Milieu Souterrain Superficiel (MSS). The Science of Nature 103: 88. https://doi.org/10.1007/s00114-016-1413-9

Mikinčić V. 1953. Geološka Karta FNR Jugoslavije i susednih Zemalja 1:500 000. Naučna Knjiga, Belgrade.

MMKS 1983. Harta gjeologjike e RPS të Shqipërisë: Shkalla 1 : 200 000. Mjeteve Mësimore, Kulturore e Sportive "Hamid Shijaku", Tirana.

Páll-Gergely B., Deli T., Erőss Z.P., Reischütz P.L., Reischütz A. \& Fehér Z. 2018. Revision of the subterranean genus Spelaeodiscus Brusina, 1886 (Gastropoda, Pulmonata, Spelaeodiscidae). ZooKeys 769:13-48. https://doi.org/10.3897/zookeys.769.25258

Reischütz A. \& Reischütz P.L. 2009. Ein Beitrag zur Kenntnis der Molluskenfauna von Montenegro, nebst Beschreibung zweier neuer Arten der Gattung Virpazaria Gittenberger 1969. Nachrichtenblatt der Ersten Vorarlberger Malakologischen Gesellschaft 16: 51-60. 
FEHÉR Z. et al., Taxonomic revision of Virpazaria (Gastropoda, Spelaeodiscidae)

Reischütz A. \& Reischütz P.L. 2012. Virpazaria nicoleae nov. spec. (Spelaeodiscidae: Pulmonata: Gastropoda) aus Montenegro. Nachrichtenblatt der Ersten Vorarlberger Malakologischen Gesellschaft 19: $17-18$.

Reischütz A., Reischütz N. \& Reischütz P.L. 2010. Beiträge zur Kenntnis der Molluskenfauna Albaniens. Nachrichtenblatt der Ersten Vorarlberger Malakologischen Gesellschaft 17: 29-31.

Reischütz A., Reischütz N. \& Reischütz P.L. 2011. Anmerkungen zur Verbreitung von Virpazaria Gittenberger 1969 (Spelaeodiscidae: Gastropoda) und bemerkenswerte Mollusken aus Albanien. Nachrichtenblatt der Ersten Vorarlberger Malakologischen Gesellschaft 18: 57-60.

Reischütz P.L., Štamol V. \& Subai P. 2012. Description of two new subspecies of Virpazaria pageti Gittenberger 1969 from Croatia (Gastropoda: Pulmonata: Spelaeodiscidae). Archiv für Molluskenkunde 141 (1): 31-34. https://doi.org/10.1127/arch.moll/1869-0963/141/031-034

Rendoš M., Čejka T., Šteffek J. \& Mock A. 2014. Land snails from subterranean traps exposed in a forested scree slope (Western Carpathians, Slovakia). Folia Malacologica 22 (4): 255-261.

https://doi.org/10.12657/folmal.022.022

Schileyko A.A. 1998. Treatise on Recent Terrestrial Pulmonate Molluscs, Part 1. Achatinellidae, Amastridae, Orculidae, Strobilopsidae, Spelaeodiscidae, Valloniidae, Cochlicopidae, Pupillidae, Chondrinidae, Pyramidulidae. Ruthenica, Supplement 2 (1): 1-127.

Schneider C.A., Rasband W.S. \& Eliceiri K.W. 2012. NIH Image to ImageJ: 25 years of image analysis. Nature Methods 9 (7): 671-675. https://doi.org/10.1038/nmeth.2089

Subai P. 2009. New land snails from Montenegro and Albania. Archiv für Molluskenkunde 138 (1): 103-112. https://doi.org/10.1127/arch.moll/0003-9284/138/103-112

Subai P. \& Dedov I. 2008. A review of the Bulgarian species of Aspasita Westerlund, 1889 (Gastropoda; Pulmonata; Spelaeodiscidae), with description of A. bulgarica spec. nov. Basteria 72: 111-118.

Welter-Schultes F.W. 2012. European Non-marine Molluscs, a Guide for Species Identification. Planet Poster Editions, Göttingen.

Manuscript received: 16 May 2019

Manuscript accepted: 1 August 2019

Published on: 26 September 2019

Topic editor: Rudy Jocqué

Section editor: Thierry Backeljau

Desk editor: Danny Eibye-Jacobsen

Printed versions of all papers are also deposited in the libraries of the institutes that are members of the EJT consortium: Muséum national d'Histoire naturelle, Paris, France; Meise Botanic Garden, Belgium; Royal Museum for Central Africa, Tervuren, Belgium; Royal Belgian Institute of Natural Sciences, Brussels, Belgium; Natural History Museum of Denmark, Copenhagen, Denmark; Naturalis Biodiversity Center, Leiden, the Netherlands; Museo Nacional de Ciencias Naturales-CSIC, Madrid, Spain; Real Jardín Botánico de Madrid CSIC, Spain; Zoological Research Museum Alexander Koenig, Bonn, Germany; National Museum, Prague, Czech Republic. 